\title{
TOOTH SIZE PREDICTION IN WHITE BRAZILIAN INDIVIDUALS: applicability of methods
}

\author{
Camilo Aquino MELGAÇO ${ }^{1}$ \\ Mônica Tirre de Sousa ARAÚJO² \\ Antônio Carlos de Oliveira RUELLAS ${ }^{2}$ \\ Samyra Maria dos Santos Nassif LACERDA ${ }^{3}$ \\ Sérgio Ricardo MAGALHÃES ${ }^{4}$ \\ Soraya de Mattos Camargo GROSSMANN ${ }^{5}$
}

Kelly Oliva JORGE ${ }^{6}$

\begin{abstract}
${ }^{1}$ Doutor em Ortodontia. Docente do curso de Odontologia da Universidade Vale do Rio Verde - UninCor, campus Belo Horizonte. E-mail: camilomelgaco@hotmail.com

${ }^{2}$ Doutor em Ortodontia. Professor do curso de Odontologia da Universidade Federal do Rio de Janeiro

${ }^{3}$ Doutora em Biologia Celular. Docente do curso de Odontologia da Universidade Vale do Rio Verde - UninCor, campus Belo Horizonte. E-mail: samyranassif@ hotmail.com

${ }^{4}$ Doutor em Engenharia Biomédica. Docente do curso de Odontologia da Universidade Vale do Rio Verde - UninCor, campus Belo Horizonte. E-mail: sergio.magalhaes@unincor.edu.br

${ }^{5}$ Doutora em Patologia Bucal. Docente do curso de Odontologia da Universidade Vale do Rio Verde - UninCor, campus Belo Horizonte. E-mail: prof.soraya.grossmann@ unincor.edu.br

${ }^{6}$ Doutora em Odontopediaria. Docente do curso de Odontologia da Universidade Vale do Rio Verde - UninCor, campus Belo Horizonte. E-mail: kellyoliva@yahoo.com.br
\end{abstract}

Recebido em: 13/04/2016 - Aprovado em: 26/05/2017 - Disponibilizado em: 01/07/2017

\begin{abstract}
Estimating the mesiodistal widths of unerupted permanent canines and premolars is an essential aspect of mixed dentition analysis that should be considered by dentists treating patients in this stage of developing occlusion. This study aims to evaluate the applicability and accuracy of three non-radiographic prediction methods (Moyers, Tanaka \& Johnston and Bernabé \& Flores-Mir) and propose new regression equations based on the sum of the widths of the lower four permanent incisors to predict the widths of lower permanent canines and premolars. The sample was consisted of 400 dental casts obtained from white Brazilian patients (200 male and 200 female). The results demonstrated that Moyers' tables at $50^{\text {th }}$ and $75^{\text {th }}$ percentile levels tend to underestimate the actual sum of the widths of lower permanent canine and premolars for male and female samples, with statistical significant differences. Although the same statistical significant differences were found when Tanaka \& Johnston's and Bernabé \& Flores-Mir's methods were used, these differences were not clinically relevant (less than $1 \mathrm{~mm}$ ). The regression equations proposed in this study are a good prediction method to determine widths of the lower permanent canine and premolars.
\end{abstract}

Keywords: Tooth Size. Prediction Method. Orthodontics. Dentistry. Linear Regression.

\section{Introduction}

The mixed dentition stage is defined as the period that permanent and deciduous teeth are present in the mouth, simultaneously. The mixed dentition analysis is performed when the four permanent mandibular incisors and the first permanent molars are erupted (BALLARD \& WILIE, 1947; BISHARA \& JAKOBSEN, 1998; FLORES-MIR et al., 2003) On average, a positive difference can be expected between deciduous teeth (canine, first and second molars) and their successors (permanent canine and premolars). This 
difference was described by Nance (1947) and was determined, on average, as $3.4 \mathrm{~mm}$ in lower arch and $1.8 \mathrm{~mm}$ in upper. It is a well established that arch length decreases during the transition from the mixed to the permanent dentition, particularly in the mandibular arch (NANCE, 1947; GIANELLY, 2002). Thus, mixed dentition analysis is commonly executed in this arch as it is critical in conquering or regaining space (MUCHA \& BOLOGNESE, 1985; PAULA \& ALMEIDA, 1987).

The prediction of mesiodistal width of unerupted permanent canines and premolars became an important and fundamental procedure to be executed in every patient during mixed dentition stage, in order to determine an accurate diagnosis and treatment plan (TANAKA \& JOHNSTON, 1974; SMITH, KING \& VALENCIA, 1979; STALEY et al., 1983; VAN DER MERWE et al., 1991; URSUS \& WILTSHIRE, 1997; MOK \& COOKE, 1998; CECÍLIO \& VIGORITO， 2001; GIANELLY， 2002; DIAGNE et al., 2003; LEGOVIC, NOVOSEL \& LEGOVIC, 2003; TAUSCHE, LUCK \& HARZER, 2004).

The methods commonly used to predict unerupted permanent canine and premolars mesiodistal widths are based on:

1- radiographs - periapical or $45^{\circ}$ cephalometric radiographs (LIMA \& MONNERAT, 1992; PAULA \& ALMEIDA, 1987; MARTINELLI et al., 2005);
2- regression equations (non radiographic methods) - prediction tables or graphics (BALLARD \& WILIE, 1947; MOYERS, 1988);

3- regression equations combined with radiographs - combination of both methods above (HIXON \& OLDFATHER, 1958; STALEY \& HOAG, 1978; STALEY \& KERBER, 1980).

All these prediction methods are not totally precise and can overestimate or underestimate the actual size of unerupted teeth (FISK \& MARKIN, 1979; MOYERS, 1988). The use of correlation-statistical methods have gained strength due to advances in statistical software and high correlation values obtained with simple and multiple regression models (BALLARD \& WILIE，1947; TANAKA \& JOHNSTON, 1974; FERGUSON et al., 1978; MOYERS, 1988; OLIVEIRA, PINZAN \& HENRIQUES, 1991; VAN DER MERWE et al., 1991; BISHARA \& JAKOBSEN, 1998; YUEN, TANG \& SO, 1998; PROFFIT \& FIELDS, 2000; NOURALLAH et al., 2002; PAIXÃO, CORDEIRO \& JÚNIOR, 2002; FLORES-MIR et al., 2003; LEGOVIC, NOVOSEL \& LEGOVIC, 2003). Thus, MOYERS' (1988) tables and TANAKA \& JOHNSTON'S (1974) method have achieved widespread clinical use and acceptance (URSUS \& WILTSHIRE, 1997; PROFFIT \& FIELDS, 2000). Most of Brazilian dentists use Moyers' tables at $75^{\text {th }}$ percentile level (PAIXÃO, CORDEIRO \& JÚNIOR, 2002). 
Unfortunately Moyers' equations do not mention the sample origin or characteristics (TANAKA \& JOHNSTON, 1974; CECÍLIO \& VIGORITO, 2001).

The accuracy of methods based in regression equations or prediction tables could be questioned when applied to a different racial group or populations of different ethnic origin (TANAKA \& JOHNSTON, 1974; INGERVALL \& LENNARTSSON, 1978; VAN DER MERWE et al., 1991; LIMA \& MONNERAT, 1992; PAULA \& ALMEIDA, 1995; URSUS \& WILTSHIRE, 1997; LEECHAN et al., 1998; JAROONTHAM \& GODFREY, 2000; PAIXÃO, CORDEIRO \& JÚNIOR, 2002).

This study aims to evaluate the applicability of three prediction methods (Moyers', Tanaka \& Johnston's, Bernabé \& Flores-Mir's) to estimate the mesiodistal widths of unerupted lower permanent canines and premolars in white Brazilian individuals from Rio de Janeiro.

\section{Materials and Methods}

Initial 400 dental casts (200 from white Brazilian female patients and 200 from white Brazilian male patients - average ages of 13.8 and 14.4 years, respectively) were selected from the archives of private orthodontic clinics in Belo Horizonte. Impressions and study casts were prepared by the use of alginate impression material and high-quality orthodontic model stone (Dental Stone Type III; Vigodent S/A Indústria e Comércio, Rio de Janeiro -RJ - Brasil).

This study was based only in the mandibular arch and all permanent teeth (excluding third molars) should be present and fully erupted. No previous orthodontic treatment, mesiodistal caries, restorations, cavities, fractures, tooth congenital defects or tooth wear should be present. No impression flaws were found. These criteria were in agreement with those proposed by many authors (HUNTER \& PRIEST, 1960; STALEY \& KERBER, 1980; VAN DER MERWE et al., 1991; LIMA \& MONNERAT, 1992; URSUS \& WILTSHIRE, 1997; LEE-CHAN et al., 1998; JAROONTHAM \& GODFREY, 2000; MARCHIONNI et al., 2001; VERZI, LEONARDI \& PALERMO, 2002; LEGOVIC, NOVOSEL \& LEGOVIC, 2003; BERNABÉ \& FLORES-MIR, 2005; MARINELLI et al., 2005).

The measures were obtained using an electronic digital caliper $(0-150 \mathrm{~mm}$ ME 00183, LEE TOOLS, Kaje Intermares Comercial Importação \& Exportação LTDA, CHINA) with accuracy of $\pm 0,02 \mathrm{~mm}$ and repeatability of $\pm 0,01 \mathrm{~mm}$ (Manufacturer Specifications). To determine measurement consistencies, one investigator measured 200 tooth mesiodistal widths, three times with intervals of 10 days (total of 600 measures). The sliding caliper was adjusted to tooth 
greatest mesiodistal diameter (contact points), parallel to the occlusal surface and perpendicular to tooth long axis, as preconized by other investigators (HIXON \& OLDFATHER, 1958; TANAKA \& JOHNSTON，1974; KAPLAN, SMITH \& KANAREK, 1977; ZILBERMAN, KAYE \& VARDIMON, 1977; BISHARA et al., 1986; BISHARA et al., 1989; URSUS \& WILTSHIRE, 1997; LEE-CHAN et al., 1998; YUEN, TANG \& SO, 1998; WARREN \& BISHARA，2001; NOURALLAH et al., 2002). Figure 1.

Fig 1. Digital caliper used in the present study.

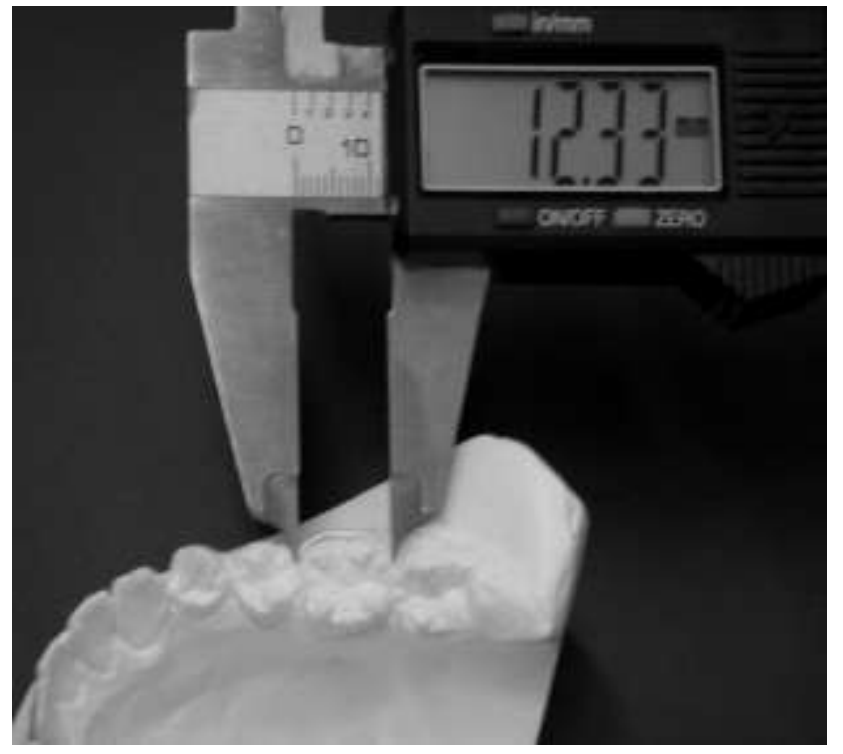

Three prediction methods were used in this study. All three methods results represent the average of right and left sides:

1. Moyers' - probability charts at the $50^{\text {th }}$ and $75^{\text {th }}$ percentile confidence levels were used to indicate the predicted sum of the widths of lower permanent canines and premolars.

2. Tanaka \& Johnston's - prediction of the sum of mesiodistal widths of inferior permanent canines and premolars was obtained summing $10.5 \mathrm{~mm}$ to the half of the lower four permanent incisors widths.

3. Bernabé \& Flores-Mir's - predicted sum of the widths of lower permanent canines and premolars were obtained by regression equation based on the following formula: $\mathrm{Y}=3.763+0.37 \times X 0$ $+1.057 \times X 1+0.366 \times X 2$, where $X 0$ is the sum of the of the upper and lower permanent central incisors plus the widths of the upper permanent first molars, $X 1$ is zero for the mandible and 1 for the maxilla, and $X 2$ is zero for female and 1 for male.

\section{Intraclass Correlation Coefficient} (ICC) was used to determine measurement consistencies. To determine right/left sides and gender differences, pared and non-pared Student's t-test was used, respectively. Pared Student's t-test was also used to compare the predicted and actual sums of the inferior permanent canines and premolars (TANAKA \& JOHNSTON, 1974; ZILBERMAN, KAYE \& VARDIMON, 1977; STALEY et al., 1983; AL-KHADRA, 1993; BISHARA \& JAKOBSEN, 1998; MARCHIONNI et al., 2001; MARTINELLI et al., 2001; WARREN \& BISHARA, 2001; FLORES-MIR et al., 2003; KESKI-NISULA et al., 2003; 
BERNABÉ, MAJOR \& FLORES-MIR, 2004; BERNABÉ, VILLANUEVA \& FLORESMIR, 2004; MARINELLI et al., 2005).

\section{Results}

High value for ICC was found (ICC $=0.995)$, indicating great precision in measure reproducibility and measure consistency. There was no statistical significant difference between left and right sides of the upper and lower arches in both gender groups. There was a significant statistical difference between male and female widths of permanent teeth in both arches. Male teeth are generally larger than female ones.

The differences and significance ( $p$ value) between actual and predicted sum of the widths of lower permanent canines and premolars obtained by Moyers', Tanaka \& Johnston's and Bernabé \& Flores-Mir's methods are demonstrated in Table I (Male) and Table II (Female).

Table I. Sum of the widths of lower permanent canine and premolars: predicted values, actual values and differences in - [millimeters. Male sample.

\begin{tabular}{lcc|cc|cc|c}
\cline { 2 - 6 } \multicolumn{1}{c|}{ MALE PATIENTS } & \multicolumn{2}{c|}{$\begin{array}{c}\text { Predicted values of } \\
\text { permanent canine } \\
\text { and premolars }\end{array}$} & $\begin{array}{c}\text { Actual values } \\
\text { of permanent } \\
\text { canine and } \\
\text { premolars }\end{array}$ & \multicolumn{2}{c|}{$\begin{array}{c}\text { Difference } \\
\text { (predicted minus } \\
\text { actual values) }\end{array}$} & $\begin{array}{c}\text { Significance } \\
\text { (p value) }\end{array}$ \\
\cline { 2 - 6 } & Mean & S.D. & Mean & S.D. & Mean & S.D. & \\
\hline Moyers 50\% (1988) & 20.21 & 0.41 & 21.41 & 1.03 & -1.20 & 0.89 & $\mathrm{p}<0.01$ \\
Moyers 75\% (1988) & 21.78 & 0.59 & 22.71 & 0.99 & -0.93 & 0.89 & $\mathrm{p}<0.01$ \\
Tanaka \& Johnston (1974) & 22.67 & 0.53 & 23.41 & 1.07 & -0.74 & 0.87 & $\mathrm{p}<0.01$ \\
Bernabé \& Flores-Mir (2005) & 22.73 & 0.94 & 22.56 & 1.23 & 0.17 & 0.84 & $\mathrm{p}<0.01$ \\
\hline
\end{tabular}

Statistical significance $p=.01$.

S.D. - standard deviation.

Table II. Sum of the widths of lower permanent canine and premolars: predicted values, actual values and differences in millimeters. Female sample.

\begin{tabular}{lcc|cc|cc|c}
\cline { 2 - 5 } \multicolumn{1}{c}{ FEMALE PATIENTS } & $\begin{array}{c}\text { Predicted values of } \\
\text { permanent canine } \\
\text { and premolars }\end{array}$ & $\begin{array}{c}\text { Actual values of } \\
\text { permanent } \\
\text { canine and } \\
\text { premolars }\end{array}$ & $\begin{array}{c}\text { Difference } \\
\text { (predicted } \\
\text { minus actual } \\
\text { values) }\end{array}$ & $\begin{array}{c}\text { Significance } \\
\text { (p value) }\end{array}$ \\
\cline { 2 - 6 } & Mean & S.D. & Mean & S.D. & Mean & S.D. & \\
\hline Moyers 50\% (1988) & 20.39 & 0.68 & 21.68 & 1.04 & -1.29 & 0.78 & $\mathrm{p}<0.01$ \\
Moyers 75\% (1988) & 21.20 & 0.67 & 21.68 & 1.04 & -0.48 & 0.78 & $\mathrm{p}<0.01$ \\
Tanaka \& Johnston (1974) & 21.88 & 0.64 & 21.68 & 1.04 & 0.20 & 0.78 & $\mathrm{p}<0.01$ \\
Bernabé \& Flores-Mir (2005) & 21.78 & 0.87 & 21.70 & 1.07 & 0.08 & 0.87 & $\mathrm{p}>0.01$ \\
\hline
\end{tabular}

Statistical significance $p \leq .01$.

S.D. - standard deviation.

In male sample it was observed that Moyers' charts at $50^{\text {th }}$ and $75^{\text {th }}$ percentile levels tended to underestimate the actual sum of the widths of lower permanent canine and premolars in $1.20 \mathrm{~mm}$ and $0.41 \mathrm{~mm}$, respectively. The standard deviation of these 
differences was $0.89 \mathrm{~mm}$ for both percentile levels. The Tanaka \& Johnston's method tended to underestimate the actual sum of the widths of lower permanent canine and premolars in $0.24 \mathrm{~mm}$ with standard deviation of $0.87 \mathrm{~mm}$. Bernabé \& Flores-Mir's method tended to overestimate the actual values in $0.17 \mathrm{~mm}$ with a standard deviation of 0.84 $\mathrm{mm}$.

In female sample it was observed that Moyers' charts at $50^{\text {th }}$ and $75^{\text {th }}$ percentile levels tended to underestimate the actual sum of the widths of lower permanent canine and premolars in $1.29 \mathrm{~mm}$ and $0.48 \mathrm{~mm}$, respectively. The standard deviation of these differences was $0.78 \mathrm{~mm}$ for both percentile levels. Tanaka \& Johnston's and Bernabé \& Flores-Mir's methods tend to overestimate the actual sum of the widths in $0.20 \mathrm{~mm}$ and 0.08 $\mathrm{mm}$ with standard deviations of $0.78 \mathrm{~mm}$ and $0.87 \mathrm{~mm}$, respectively.

Based on these results and in order to improve the correlation between predicted and actual values of lower permanent canine and premolars, the following regression equation was proposed: $\mathrm{Y}=\mathrm{a}+\mathrm{bX}$

"Y" represents the sum of predicted mesiodistal widths (in millimeters) of the lower permanent canine and premolars in one quadrant; "X" represents the mesiodistal widths of the lower four permanent incisors in millimeters. The constant " $a+b$ " represents the constants to be derived, "a" is the $y$ intercept and " $b$ " is the slope of the regression line. The equations are presented below only for the lower arch:

Male patients : $\mathrm{Y}=8.9+0.58 \mathrm{X}$.

Female patients : $\mathrm{Y}=9.2+0.55 \mathrm{X}$.

The regression equation provided new values for the predicted sum of the mesiodistal widths of the lower permanent canines and premolars. These predicted values are compared to actual ones in Table III.

Table III. Mean values, standard deviation, difference in millimeters and significance between predicted and actual values of the lower permanent canines and premolars (regression equation determined in the present study).

\begin{tabular}{lcc|cc|cc|c} 
& \multicolumn{2}{c|}{$\begin{array}{c}\text { Predicted values based } \\
\text { on regression equation }\end{array}$} & \multicolumn{2}{|c|}{$\begin{array}{c}\text { Actual values of } \\
\text { permanent canine and } \\
\text { premolars }\end{array}$} & Difference & \multirow{2}{*}{$\begin{array}{c}\text { Significance } \\
\text { (p value) }\end{array}$} \\
\cline { 2 - 6 } & Mean & S.D. & Mean & S.D. & Mean & S.D. & \\
\hline Female* & 21.74 & 0.75 & 21.70 & 1.34 & 0.04 & 0.77 & $\mathrm{p}>0.01$ \\
Male* & 22.59 & 0.87 & 22.56 & 1.23 & 0.03 & 0.87 & $\mathrm{p}>0.01$ \\
\hline
\end{tabular}

* sample size $=200$ cases

S.D. - standard deviation.

Statistical significance $p=.01$. 
The difference between predicted and actual widths was, on average, $0.03 \mathrm{~mm}$ for male and $0.04 \mathrm{~mm}$ for female patients. The standard deviation of the difference was 0.77 $\mathrm{mm}$ for female and $0.87 \mathrm{~mm}$ for male patients. There were no statistical significant differences between predicted and actual widths of lower permanent canines and premolars for each male and female sample ( $\mathrm{p}$ value 0.444 and 0.622 , respectively).

The values of constants " $a$ " and " $b$ " found in this study are compared among other studies in Table IV.

Table IV. Comparison among various values of "a" and "b" constants.

\begin{tabular}{lcc} 
& \multicolumn{2}{c}{ Regression Coefficients } \\
\cline { 2 - 3 } & a & b \\
\hline Present Study & 9.20 (female) / 8.90 (male) & 0.55 (female) / 0.58 (male) \\
Ballard \& Wylie (1947) & 9.41 & 0.52 \\
Tanaka \& Johnston (1974) & 9.18 & 0.54 \\
Ferguson et al. (1978) & 9.93 & 0.52 \\
Moyers (1988)* & 8.25 (female)/10.79 (male) & 0.52 (female) /0.45 (male) \\
Van Der Merwe et al. (1991) & 7.46 & 0.60 \\
Al-Khadra (1993) & 8.60 & 0.55 \\
Jaroontham \& Godfrey (2000) & 10.30 & 0.50 \\
Chan et al. (1998) & 7.46 & 0.62 \\
Diagne et al. (2003) & 5.67 & 0.70 \\
\hline
\end{tabular}

* regression equations derived from Moyers' tables (1988) at the $50^{\text {th }}$ percentile.

Correlation and determination coefficients were also determined. These coefficients were compared to other ones obtained in different studies (Table V).

Table V. Comparison among correlation (r) and determination $\left(\mathrm{r}^{2}\right)$ coefficients found in this and other studies.

\begin{tabular}{cccc|ccc|cr} 
& \multicolumn{2}{c|}{ Male } & \multicolumn{2}{c|}{ Female } & \multicolumn{3}{c}{ Male+Female } \\
\cline { 2 - 7 } & $\mathrm{r}$ & $\mathrm{r}^{2}$ & $\mathrm{r}$ & $\mathrm{r}^{2}$ & \multicolumn{1}{r}{} & $\mathrm{r}^{2}$ \\
\hline Present study & 0.704 & 0.496 & 0.694 & 0.482 & - & - \\
Tanaka \& Johnston (1974) & - & - & - & - & 0.648 & - \\
Bernabé \& Floris-Mir (2005) & 0.710 & - & 0.720 & - & - & 0.604 \\
\hline
\end{tabular}

- coefficient not determined.

\section{Discussion}

Particularities of mixed dentition analysis, as tooth size discrepancies, differ among population. Some of the most used methods to predict widths of unerupted permanent teeth were developed for American children (HIXON \& OLDFATHER, 1958; TANAKA \& JOHNSTON, 1974; MOYERS, 1988). Studies to confirm the applicability and effectiveness of these methods in different populations are justified.

A digital caliper was used to determine more accurate and precise measures and reduce eye 
fatigue. The use of this kind of caliper is recommended by several authors (FERGUSON et al., 1978; BISHARA \& JAKOBSEN, 1998; MOK \& COOKE, 1998; YUEN, TANG \& SO, 1998; WARREN \& BISHARA, 2001; KESKI-NISULA et al., 2003). The value of ICC (0.995) found in this study in accordance to the values found by other investigators (HIXON \& OLDFATHER, 1958; FERGUSON et al., 1978; STALEY \& KERBER, 1980; STALEY et al., 1983; BERNABÉ, MAJOR \& FLORES-MIR， 2004; BERNABÉ \& FLORES-MIR, 2005). This indicates great measurement precision, repeatability and consistence. Thus, all measures from the 400 dental casts were performed only once.

The results demonstrated no difference between right and left sides of the lower and upper arch. All methods used in this study predict one side of the arch (average of right and left sides). In order to determine the predicted sum of the widths of permanent canines and premolars of both sides, the results must be multiplied by 2 (TANAKA \& JOHNSTON, 1974; MOYERS, 1988; BERNABÉ \& FLORES-MIR, 2005).

A statistical significant difference was found between male and female tooth mesiodistal widths. Male teeth are generally larger. The literature also describes gender differences in tooth widths (MOYERS, 1988; BISHARA \& JAKOBSEN, 1998; VAN DER MERWE et al., 1991; PAULA, ALMEIDA \&
LEE， 1995; LEGOVIC, NOVOSEL \& LEGOVIC, 2003; CABRAL et al., 2004; BERNABÉ \& FLORES-MIR, 2005). However, other studies do not consider gender differences (HIXON \& OLDFATHER, 1958; TANAKA \& JOHNSTON, 1974; VAN DER MERWE et al., 1991; LIMA \& MONNERAT, 1992; ALKHADRA， 1993; MARTINELLI et al., 2005). The data were analyzed separately for each gender. No better correlation or determination coefficient was found when male and female samples were analyzed together.

In both male and female samples, Moyers' tables at $50^{\text {th }}$ and $75^{\text {th }}$ percentile level tended to underestimate the actual sum of the widths of lower permanent canine and premolars. The differences between predicted and actual values were statistically significant (Tables I and II). These results are in accordance to many studies (VAN DER MERWE et al., 1991; URSUS \& WILTSHIRE, 1997; PAIXÃO, CORDEIRO \& JÚNIOR, 2002; CABRAL ET AL., 2004), but they do not agree with others that found that these percentile levels (specially $75^{\text {th }}$ ) tend to overestimate the actual sum of the widths of lower permanent canines and premolars (FISK \& MARKIN, 1979; PAULA \& ALMEIDA, 1987; AL-KHADRA, 1993; BISHARA \& JAKOBSEN, 1998; DIAGNE et al., 2003). However, some authors found no differences when Moyers' method $\left(75^{\text {th }}\right.$ 
percentile) was used (LIMA \& MONNERAT, 1992; PAULA \& ALMEIDA, 1987; MARCHIONNI, SILVA \& ARAÚJO, 2001; FLORES-MIR et al., 2003). This variability in results may be explained by the differences in sample sizes and origins.

Although statistically significant $(\mathrm{p}<0.01)$, no clinical relevant difference was found between the predicted and actual sum of the widths of lower permanent canine and premolars when Tanaka \& Johnston's method was applied in male and female samples (Tables I and II). These results are in accordance to some studies (PAULA \& ALMEIDA, 1987; MARCHIONNI, SILVA \& ARAÚJO, 2001; FLORES-MIR et al., 2003). However, other authors found overestimated results when Tanaka \& Johnston's method was used (BISHARA \& JAKOBSEN, 1998; LIMA \& MONNERAT, 1992; PROFFIT \& FIELDS, 2000). The method proposed by Bernabé \& Flores-Mir's was tested in the Brazilian sample and no statistical difference was found between predicted and actual sum of the widths of lower permanent canine and premolars in female group. In male group, although the results demonstrated statistical differences, no clinical relevant difference was observed (Tables I and II).

In the present study, new regression equations were developed using the widths of the lower four permanent incisors as predictors for the sum of the widths of lower permanent canine and premolars. The correlation coefficients found (Table V) are higher than those porposed by Tanaka \& Johnston's and are similar to those described by Bernabé \& Flores-Mir. The standard deviation of the differences is in accordance to those related in the literature (TANAKA \& JOHNSTON, 1974; STALEY et al., 1983; LIMA \& MONNERAT, 1992; BISHARA \& JAKOBSEN, 1998; NOURALLAH et al., 2002; DIAGNE et al., 2003; BERNABÉ \& FLORES-MIR, 2005; MARTINELLI et al., 2005).

High value of ICC $($ ICC $=0.995)$ was found, indicating great measurement precision and repeatability. This value of ICC is similar to those described by the literature (HIXON \& OLDFATHER, 1958; STALEY \& HOAG, 1978; STALEY \& KERBER, 1980; MUCHA \& BOLOGNESE, 1985; YUEN, TANG \& SO, 1998; CABRAL et al., 2004). Thus, tooth mesiodistal widths of all 400 casts were measured only once.

Several authors demonstrated differences between male and female tooth widths (NANCE, 1947; STALEY \& HOAG, 1978; SMITH, KING \& VALENCIA, 1979; STALEY et al., 1983; MUCHA \& BOLOGNESE, 1985; MOYERS, 1988; ALKHADRA，1993; PAULA \& ALMEIDA, 1987; URSUS \& WILTSHIRE, 1997; BISHARA \& JAKOBSEN, 1998), although others do not consider gender differences (MOYERS, 1988; VAN DER MERWE et al., 
1991; BERNABÉ \& FLORES-MIR, 2005; LIMA \& MONNERAT, 1992; HIXON \& OLDFATHER, 1958; STALEY \& KERBER, 1980). This study also found a statistical difference between male and female tooth widths. Male teeth are generally larger. Data were analyzed separately for male and female samples. In this study, the differences between right and left sides of the lower arch were small and not statistically significant. This symmetry was confirmed by many investigators (STALEY \& HOAG, 1978; ALKHADRA，1993; PAULA \& ALMEIDA, 1987; URSUS \& WILTSHIRE, 1997; BISHARA \& JAKOBSEN, 1998; MARCHIONNI, SILVA \& ARAÚJO, 2001).

\section{Conclusion}

Considering the studied sample and the results found in this study, one can conclude:

\section{References}

1. AL-KHADRA B.H. Prediction of the size of unerupted canines and premolars in a Saudi Arab population. Am J Orthod Dentofacial Orthop 1993; 104: 369-372.

2. BALLARD M.L.; WILIE W.L. Mixed dentition case analysis - estimating size of unerupted permanent teeth. Am J Orthod 1947; 33: 754-759.

3. BERNABÉ E.; FLORES-MIR C. Are the lower incisors the best predictors for the unerupted canine and
1. no clinical relevant difference was observed between predicted and actual widths of the lower permanent canine when the methods proposed by Tanaka \& Johnston (1974) and Bernabé \& Floris-Mir (2005) were applied in the studied sample;

2. the predicted widths determined by Moyers' tables at $50^{\text {th }}$ and $75^{\text {th }}$ percentiles underestimate the actual widths of the lower permanent canine and premolars for male and female patients. These differences were statistically significant;

3. the regression equations proposed in this study are a good prediction method to determine widths of the lower permanent canine and premolars in the studied Brazilian population.

premolars sums? An analysis of a Peruvian sample. Angle Orthod 2005; 75 (2): 198-203.

4. BERNABÉ E.; MAJOR P.W.; FLORES-MIR C. Tooth-width ratio discrepancies in a sample of Peruvian adolescents. Am J Orthod

Dentofacial Orthop 2004; 125 (3): 361-365.

5. BERNABÉ E.; VILLANUEVA K.M.; FLORES-MIR C. Tooth Width Ratios in Crowded and Noncrowded Dentitions. Angle Orthod 2004; 74 (6): 765-768. 
6. BISHARA S.E.; JAKOBSEN J.R. Comparison of two nonradiographic methods of predicting permanent tooth size in the mixed dentition. Am J Orthod Dentofacial Orthop 1998; 114 (5): 573-576.

7. BISHARA S.E.; GARCIA A.F.; JAKOBSEN J.R.; FAHL J.A.

Mesiodistal crown dimensions in Mexico and the United States. Angle Orthod 1986; 56 (4): 315-323.

8. BISHARA S.E.; JAKOBSEN J.R.; ABDALLAH E.M.; GARCIA A.F. Comparisons of mesiodistal and buccolingual crown dimensions of the permanent teeth in three populations from Egypt, Mexico, and the United States. Am J Orthod Dentofacial Orthop 1989; 96 (5): 416 - 422.

9. CABRAL E.D.; CALDAS JR. A.F.; FILHO H.C.; CALDAS S.G.F.R. Avaliação das tabelas de Moyers para estimar a largura de canino e premolars - um estudo em Natal-RN. J Bras Ortodon Ortop Facial 2004; 9 (49): 37-40.

10. CECÍLIO E.; VIGORITO J.W. Avaliação do índice de Moyers na predição das dimensões mésio-distais de caninos e premolares em pacientes adolescentes, brasileiros, leucodermas, do sexo masculino e feminino.

Ortodontia 2001; 34 (01): 8-15.

11. DIAGNE F.; DIOP-BA K.; NGOM P.I.; MBOW K. Mixed dentition analysis in a Senegalese population: elaboration of prediction tables. Am J Orthod Dentofacial Orthop 2003; 124 (2): 178-183.

12. FISK R.O.; MARKIN S. Limitations of the mixed dentition analysis.

Ontario Dentist 1979; 56 (6): 16-20.

13. FERGUSON F.S.; MACKO D.J.; SONNENBERG E.M.; SHAKUN
M.L. The use of regression constants in estimating tooth size in a Negro population. Am J Orthod 1978; 73 (1): 68-72.

14. FLORES-MIR C.; BERNABÉ E.; CAMUS C.; CARHUAYO M.A.; MAJOR P.W. Prediction of mesiodistal canine and premolar width in a sample of Peruvian adolescents. Orthod Craniofacial Res 2003; 6 (3): 173-176.

15. GIANELLY A.A. Treatment of crowding in the mixed dentition. Am J Orthod Dentofacial Orthop 2002; 121 (6): 569-571.

16. HIXON E.H.; OLDFATHER R.E. Estimation of the sizes of unerupted cusp and bicuspid teeth. Angle Orthod 1958; 28 (4): 236-240.

17. HUNTER W.S.; PRIEST W.R. Errors and discrepancies in measurement of tooth size. J Dent Res 1960; 39 (2): 405-414.

18. INGERVALL B.; LENNARTSSON B. Prediction of breadth of permanent canines and premolars in the mixed dentition. Angle Orthod 1978; 48 (1): 62-69.

19. JAROONTHAM J.; GODFREY K. Mixed dentition space analysis in a Thai population. Eur J Orthod 2000; 22: $127-134$.

20. KAPLAN R.G.; SMITH C.C.; KANAREK P.H. An analysis of three mixed dentition analysis. J Dent Res 1977; 56 (11): 1337-1343.

21. KESKI-NISULA K.; LEHTO R.; LUSA V.; KESKI-NISULA L.; VARRELA J. Occurrence of malocclusion and need of orthodontic treatment in early mixed dentition. Am J Orthod Dentofacial Orthop 2003; 124 (6):631-638. 
22. LIMA E.M.S.; MONNERAT M.E.

Comparação das predições do somatório dos diâmetros mésio-distais de pré-molares e caninos permanentes inferiores com seus valores reais. MS thesis. Rio de Janeiro: Universidade Federal do Rio de Janeiro: 1992.

23. LEE-CHAN S.; JACOBSON B.N.; CHWA K.H.; JACOBSON R.S. Mixed dentition analysis for AsianAmericans. Am J Orthod Dentofacial Orthop 1998; 113 (3): 293-299.

24. LEGOVIC M.; NOVOSEL A.; LEGOVIC A. Regression equations for determining mesiodistal crown diameters of canines and premolars. Angle Ortho 2003; 73 (3): 314-318.

25. MARCHIONNI V.M.T.; SILVA M.C.A.; ARAÚJO T.M.; REIS S.R.A. Avaliação da efetividade do método de Tanaka \& Johnston para predição do diâmetro mésio-distal de caninos e pré-molares não-irrompidos. Pesqui Odontol Bras 2001; 15 (1): 35-40.

26. MARTINELLI F.S.L.; ROCHA R.; MENEZES L.M.; LOCKS A.; RIBEIRO GU. Avaliação do desempenho de três métodos para o cálculo do diâmetro mésio-distal de caninos e pré-molares inferiores durante o período da dentadura mista. R Dental Press Ortodon Ortop Facial 2001; 6 (2): 63-70.

27. MARTINELLI F.L.; LIMA E.M.; ROCHA R.; ARAÚJO MST.

Prediction of lower permanent canine and premolars width by correlation methods. Angle Orthod 2005; 75 (n. 3): 236-240.

28. MOK K.H.; COOKE M.S. Space analysis: a comparison between sonic digitization (DigiGraph Workstation) and the digital caliper. Eur J Orthod 1998; 20: 653-661.
29. MOYERS R.E. Handbook of orthodontics, $4^{\text {th }}$ ed. Chicago: Year Book. 1988: 235-239.

30. MUCHA J.N.; BOLOGNESE A.M. Análise de modelos em orthodontia. RBO 1985; 40 (1): 28-44.

31. NANCE H.N. The limitations of orthodontic treatment I - mixed dentition diagnosis and treatment. Am J Orthod Oral Surg 1947; 33 (4): 177-223.

32. NOURALLAH A.W.; GESCH D.; KHORDAJI M.N.; SPLIETH C. New regression equations for predicting the size of unerupted canines and premolars in a contemporary population. Angle Orthod 2002; 72: 216-221.

33. OLIVEIRA A.G.; PINZAN A.; HENRIQUES J.F.C. Avaliação da análise de Moyers para predição do tamanho mesiodistal dos caninos e pré-molares, não irrompidos, na dentadura mista, em pacientes da região de Bauru. Ortodontia 1991; 24 (1): 18-23.

34. PAIXÃO R.F.; CORDEIRO R.C.L.; JÚNIOR L.G. Determinação do diâmetro mésio-distal de dentes caninos e premolares em indivíduos Brasileiros da região de Araraquara. $\mathbf{R}$ Dental Press Ortodon Ortop Facial 2002; 7 (5): 45-53.

35. PAULA S.; ALMEIDA M.A. Análise comparativa entre métodos de predição do diâmetro mésio-distal de caninos e pré-molares nãoerupcionados. R Bras Odontol 1987; XLIV (6): 16-23.

36. PAULA S.; ALMEIDA M.A.O.; LEE P.C.F. Prediction of mesiodistal diameter of unerupted lower canines and premolars using $45^{\circ}$ cephalometric radiography. Am J 
Orthod Dentofacial Orthop 1995;

107: 309-314.

37. PROFFIT W.R.; Fields H.W.

Contemporary Orthodontics $3^{\text {rd }}$ ed. St Louis: Mosby Co; 2000: 741p.

38. SMITH H.P.; KING D.L.; VALENCIA R.A. Comparison of three methods of mixed dentition analysis. J Pedodont 1979; Summer: 291-302.

39. STALEY R.N.; HOAG J.F. Prediction of the mesiodistal widths of maxillary permanent canines and premolars. Am J Orthod 1978; 73 (2): 169-177.

40. STALEY R.N.; KERBER P.E. A revision of the Hixon and Oldfather mixed-dentition prediction method. Am J Orthod 1980; 78 (3): 296-302.

41. STALEY R.N.; HU P.; HOAG J.F.; SHELLY T.H. Prediction of the combined right and left canine and premolar widths in both arches of the mixed dentition. Pediatric Dent 1983; 5 (n.1): 57-60.

42. TANAKA M.M.; JOHNSTON L.E. The prediction of the size of unerupted canines and premolars in a contemporary orthodontic population. J Am Dent Assoc 1974; 88 (april): 798-801.

43. TAUSCHE E.; LUCK O.; HARZER W. Prevalence of malocclusion in the early mixed dentition an orthodontic treatment need. Eur J Orthod 2004; 26 (3): 237-244.
44. URSUS R.S.; WILTSHIRE W.A. Orthodontic probability tables for black patients of African descent: mixed dentition analysis. Am J Orthod Dentofacial Orthop 1997; 112 (5): $545-551$.

45. VAN DER MERWE S.W.; ROSSOUW P.; VAN WYK KOTZE T.J.; TRUTERO H. An adaptation of the Moyers mixed dentition space analysis for a Western Cape Caucasian population. J Dental Assoc of South Africa 1991; 46: 475-479.

46. VERZI P.; LEONARDI M.; PALERMO F. Analisi dello spazio medio delle arcate dentarie in un campione di soggetti della Sicilia orientle. Minerva Stomatol 2002; 51 (7-8): 327-339.

47. WARREN J.J.; BISHARA S.E. Comparison of dental arch measurements in the primary dentition between contemporary and historic samples. Am J Orthod Dentofacial Orthop 2001; 119 (3): 211-215.

48. YUEN K.K.W.; TANG E.L.K.; SO L.L.Y. Mixed dentition analysis for Hong Kong Chinese. Angle Orthod 1998; 68 (1): 21-28.

49. ZILBERMAN Y.; KAYE E.K.; VARDIMON A. Estimation of mesidistal width of permanent canines and premolars in early mixed dentition. J Dent Res 1977; 56 (8): 911-915. 